\title{
Emerging Dimension in Management (Finance) - Corporate Debt Refinancing
}

\author{
A. Hema and Dr.G. Manokaran
}

\begin{abstract}
Corporate Debt Refinancing (CDR) is a new and emerging concept in finance. The article help to learn more about debt refinancing, the survey made with European markets from Borrower and Lender on growth of debt for 3 years (2011 to 2013). Due to competitive environment, the firm undergo refinancing or restructuring of existing policy. The reason for refinancing is reduction of interest rates or the extension of the loan's terms. A study made in this paper to know more about debt refinancing a case issue with Essar Groups and Suzlon Energy Company. To maintain a corporate financial health and credit rating improvement create interest rate lower. Most of the Indian corporate decided to undergo the concept of refinancing makes a rupee loans with cheaper dollar credit. This paper discusses the risk element and crises in the financing market. A study reveals the how Essar group company refinancing of overseas loan for their survival in global market and Suzlon recast their debt for further operation. However, Refinancing debt is a difficult and expensive process, particularly for corporation. Debt Refinancing is a supportive element for a cash flow and firm need a sound asset management to implement this concept.
\end{abstract}

Keywords--- Debt Refinancing, Refinancing Risk, Borrower and Lender survey, Interest Rate, Refinancing Risk

\section{INTRODUCTION}

$\mathrm{T}$ HE most important thing is to have a realistic understanding of the company's credit rating and prospects for future business. Basically, the fears concerning an upcoming 'wall of refinancing' have largely been abated to a number of borrowers moving early to secure funding requirements. Nevertheless, lenders predict continued pressure on debt markets in the year ahead as companies seek to fund growth strategies amidst relentless volatility. The article consists of methodology based on conceptual views and secondary data will be analysed by an author.

The study reveals the case issue of debt refinancing made by companies like Essar Group and Suzlon Energy. Essar group is the first Indian corporate for refinancing expensive rupee loans with cheaper dollar credit from the Reserve Bank of India (RBI) for \$27-billion.

A. Hema, Research Scholar in Management Studies, Sree Saraswathi Thyagaraja College, Pollachi, India. E-mail: hphema2@gmail.com

Dr.G. Manokaran, Assistant Professor, Department of Management Studies, Sree Saraswathi Thyagaraja College, Pollachi, India. E-mail: Manokarang@yahoo.co.in

DOI: 10.9756/BIJIEMS.4380
Survey made by Debtwire's 2012 Refinancing Report regarding market respondents in the Borrower and Lender communities. When a corporate wants to refinance its debt, it should see a favourable market conditions or the strengthening of a company's credit rating may lead to the refinancing of corporate debt. The two primary factors for influencing a company to refinance are decreases in the interest rate or improvements in the company's credit quality.

\section{MEANing AND Definition}

The concept of Corporate Debt Refinancing will often says about a company is unable to meet its current obligations and needs to restructure the terms of its existing debt arrangement. This usually involves lowering the interest rate and extending the time to maturity. Refinancing occur when interest rates have fallen in the market, as the lower current market rates allows a company to cut down on the overall costs of debt.

Debt Refinancing refers to the conversion of the original debt including arrears, into a new debt instrument. In other words, overdue payments or future debt-service obligations are "paid off" using a new debt obligation ${ }^{[1]}$. Debt Refinancing involves raising new money to repay existing debt. It is often done and should not be confused with debt restructuring, a more fundamental process in which a borrower changes the structure of its debts (this usually happens when a borrower is unable to meet it's obligations), this may involve a reorganization of its liabilities, for instance by converting debt into equity. Debt Rescheduling refers to a delay in the repayment of a debt, usually applying to both interest and principal payments, and can involve a renegotiation of the terms of the debt.

Refinancing may also involve issuing equity to pay off a percentage of debt. Debt is replaced or refunded by a company with money that is raised by issuing or creating other borrowing. In restructuring, a company works with its creditor to change the terms of a loan include the reduction of interest rates, the improvement of covenants or the extension of the loan's terms. ${ }^{[2]}$

\section{REFINANCE IN INDIA}

Various reasons why people go for refinancing a loan or mortgage may last for long term and a lot can happen during the time span. Through refinance, one can borrow more money on the asset and the terms \& conditions of refinancing may vary widely by country, province, or state, based on several economic factors such as, inherent risk, projected risk, political stability of a nation, currency stability, banking regulations, borrower's credit worthiness, and credit rating of a nation. In many industrialized nations, a common form of refinancing is a 
place of primary residency mortgage. If the replacement of debt occurs under financial distress, refinancing might be referred to as Debt Restructuring ${ }^{[3] \text {. }}$

Another trigger for corporate debt refinancing is when the price of their common stock reaches a level that makes it attractive for a firm to replace its outstanding debt with equity. Aside from reducing interest costs, gives a firm additional flexibility for future financing because by retiring debt they will have some unused debt capacity.

\section{i. $\quad$ Types of Refinance in India}

Refinance can be of the following types as

\section{- NO-Closing Cost}

In no-closing cost refinances one get new mortgage loan after paying some upfront fees. This type of refinance can be beneficial provided the prevailing market rate is lower than the borrower's existing rate by a formula determined by the lender offering the loan at least by 1.5 percentage points. However, one needs to pay Yield Spread Premium (YSP) to the mortgage company.

\section{- Cash-Out}

Cash-out is suitable for home improvement as well as credit card and other debt consolidation if the borrower qualifies with their current home equity. This type of refinance may not help lower the monthly payment or shorten mortgage periods. They can refinance with a loan amount larger than their current mortgage and keep the cash out.

\section{ii. Advantage of Refinance}

People opt for refinance to reduce the rate of interest on the existing loan amount. One can also opt for refinance to extend the repayment time, reduce or alter risk, to pay a dividend, to bring up cash for investment consumption, or to reduce periodic payment obligations etc. The various advantage as follows

- Refinance may result in bringing down the monthly payment amount by changing the rate of interest.

- It may also change the maturity term of the loan.

- Refinance can also improve the overall cash flow.

- Refinancing can be used to pay off high-interest debt like credit card debt with a low-interest one.

- Monthly recurring bills on the existing loan can also be paid off through refinance.

\section{iii. Disadvantage of Refinancing Debt}

Refinancing debt may seem attractive option in the short term. However, they usually have disadvantage when viewed over the term of loan including

- Have to pay existing fees to get out of existing loan early.

- The fees and charge of setting up and maintaining a new loan is likely to be more expensive than if we had to kept our existing loan

- Change the unsecured debt into debt secured over the home, and equity will be reduced and paying off the debt for a longer time, making it more expensive ${ }^{[4]}$.

\section{DEBT REFINANCING RISK AND REQUIREMENT}

Refinancing risk is the possibility that a borrower cannot refinance by borrowing to repay existing debt. Many types of commercial lending incorporate balloon payments at the point of final maturity often, the intention or assumption is that the borrower will take out a new loan to pay the existing lenders.

- A borrower that cannot refinance their existing debt and does not have sufficient funds on hand to pay their lenders may have a liquidity problem. The borrower may be considered technically insolvent: even though their assets are greater than their liabilities, they cannot raise the liquid funds to pay their creditors. Insolvency may lead to bankruptcy, even when the borrower has a positive net worth.

- Most commercial banks provide long term loans, and fund their operation by taking shorter term deposits. In general, refinancing risk is only considered to be substantial for banks in cases of financial crisis, when borrowing funds, such as inter-bank deposits, may be extremely difficult.

- Refinancing is also known as "rolling over" debt of various maturities, and so refinancing risk may be referred to as rollover risk.

Debt refinancing is an authorized B\&I purpose when it is in keeping with the program's underlying goal i.e., to create and save jobs in rural areas. This standard is typically met either by both points

\section{Improving Cash Flow}

The B\&I loan must provide improved cash flow by offering better rates \& terms than the debt being refinanced. A $20 \%$-orbetter reduction in debt service cost is desirable, but not essential. The refinance of a loan with a balloon payment clearly improves cash flow significantly (even if the annual debt service cost is not reduced) and is therefore authorized.

\section{Support Business Expansion}

Debt refinancing is allowed if it is being done in connection with a business expansion project and the refinancing is necessary for the lender to obtain the lien priority position it requires.

3. The debt being refinanced was used for 504-eligible fixed assets: to acquire land, including a building, to construct a building or to purchase equipment/fixtures.

4. The company agree to lower payments on the existing loan, but do not allow the creditor to refinance that loan, which may involve prepayment penalties, new closing costs, and perhaps even a higher interest rate and never allow the company to add new security - such as your home.

\section{i. Reason for Refinancing}

Refinancing should only be undertaken after a thorough cost/benefit analysis of all options available and also important to understand all the implications before refinancing. Refinancing may provide a range of new opportunities for your business. The key points are 
- More debt is needed to finance an expansion of the business for growth, operational or strategic reasons

- Gaining a lower interest rate from a different lender or from a different mix of debt products.

- Changing the financial cash flow commitment required to fund debt (e.g. fully

- drawn advance to an overdraft)

- Consolidating debts to minimise and simplify repayments and Releasing security over personal assets and/or specific assets as the business reaches a level of maturity at which point it has independent security to offer ${ }^{[5]}$.

\section{ii. $\quad$ Mortgage Refinancing}

The method of analyzing the refinancing decision is also applicable to mortgage refinancing for residential or commercial real estate. To decide which refinancing alternative is the best, the analysis would be similar to the corporate decision ${ }^{[6]}$. For a mortgage it would undergo 3 steps as follows:

1. Calculate the present value of the after-tax cash flows of the existing mortgage.

2. Calculate the present value of the after-tax cash flows of the proposed mortgage.

3. Compare the outcomes and select the alternative with the lower present value. The interest rate to be used in steps one and two is the after-tax interest cost of the proposed mortgage.

\section{DEBTWIRE REFINANCING REPORT}

This Report gives a detailed view of a survey of 50 representatives from the borrower community (split between private equity firms and corporate) and 50 representatives from the lender community, with their views of market conditions ahead of their refinancing plans ${ }^{[7]}$.

\section{i. Borrower Survey}

Majority of borrower respondents expect refinancing to total less than $€ 5$ bn to 2015.It has an direct impact with Indian market.

\section{- Sector wise Refinancing of Debt}

In 2011 many private equity owned businesses termed out their debt in the leveraged loan and bond markets, such that the balance of 2013 maturities is now dominated by corporate borrowers. The chart reveals level of debt refinanced by people in European market.

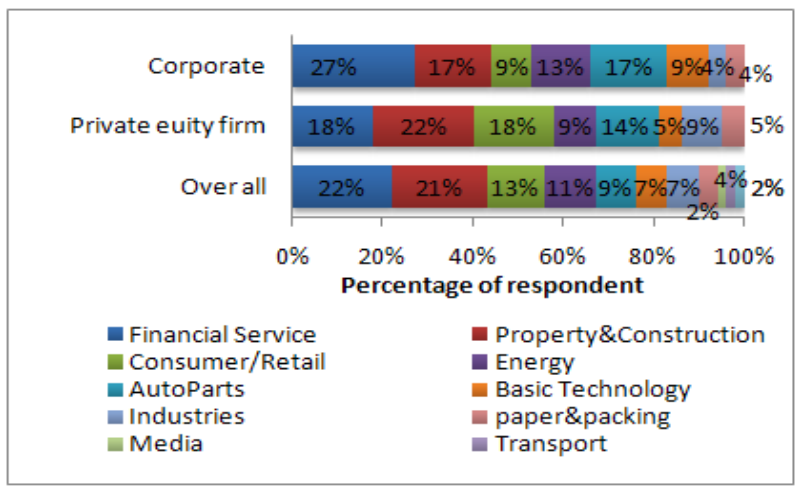

Figure 2

\section{- Provider Survey in the Market}

Banks are set to remain the key providers of capital and many companies will not have the ability to reach the bond market and would not be interested in private equity. Private equity and alternative capital providers play substantial roles in refinancing.

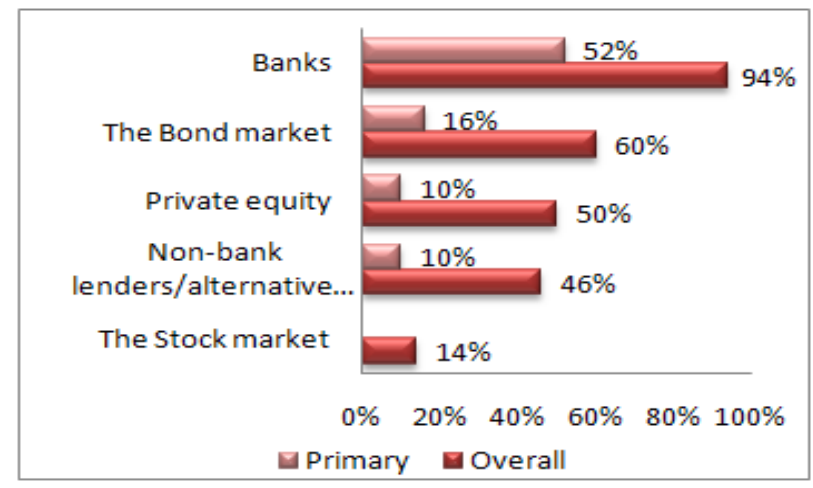

Figure 3

\section{ii. Lender Survey}

\section{- Sector wise Refinancing Lender}

In the Figure-5, Financial Services will account for the bulk of the upcoming refinancing, according to the above survey in European market said by participant a high percentage of bank loans are stuck in the Property \& Construction sector and a lot of them have already become non-performing, and a leveraged loan market. Now, governments are stepping in to safeguard the interests of banks and reduce defaults.

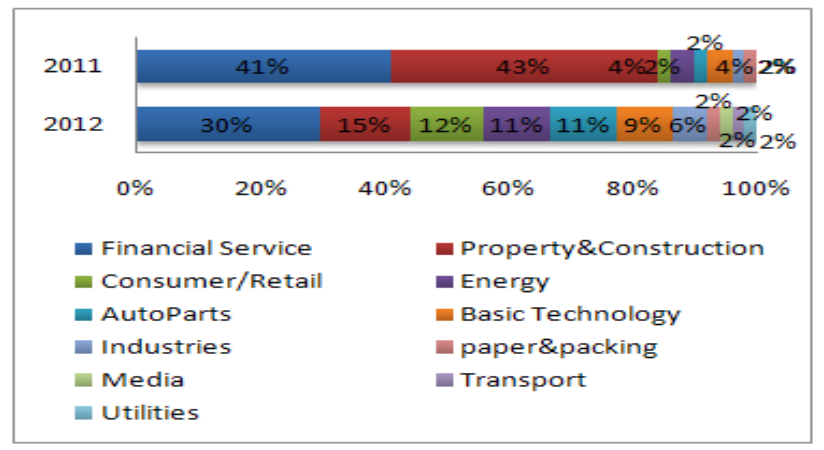

Figure 5 
- Survey of Lender Provider in the Market

The Figure -6 shows the most refinancing will not happen until at least the second half of 2012 due to the high level of uncertainty and challenges in European Sovereign debt crisis, high unemployment rates, national elections and growth driven by Asia countries.

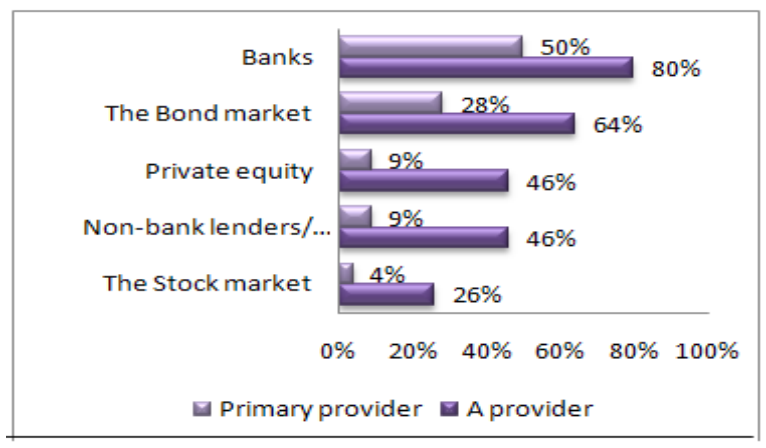

\section{CASE STUdy ON ESSAR GROUP COMPANIES \& SUZLON ENERGY COMPANIES}

\section{i. $\quad$ Case Study on Essar Group Companies}

Essar Global Ltd plans to refinance $\$ 3.5$ billion of overseas loans, while Essar Steel Ltd will take on new debt to repay as much as 70 billion rupees ( $\$ 1.3$ billion) of borrowing through external commercial borrowing ${ }^{[10]}$. Essar Steel has a total debt of about 230 billion rupees and it has spent most of the funds to more than double capacity, under the Corporate Debt Refinancing Mechanism ${ }^{[8]}$. Essar Oil had 156.3 billion rupees in debt and 20.6 billion rupees of cash. Essar Ports Ltd initially refinance from Rs.5, 500 crore to Rs.1, 000 crore through longterm financing ${ }^{[9]}$. Essar Energy plans to refinance up to $\$ 1.5$ billion of its rupee debt within a couple of quarters ${ }^{[10]}$.

\begin{tabular}{|l|l|l|}
\hline Company & Debt & Refinanced debt \\
\hline Essar global & $\$ 3.5$ billion & $\$ 1.3$ billion \\
\hline Essar steel & $\$ 430$ million & $\$ 750$ million \\
\hline Essar oil & $\$ 156.3$ billion & $\$ 55.6$ billion \\
\hline Essar port & RS.5500 crore & Rs.1000 crore \\
\hline
\end{tabular}

\section{- Suggestion}

Essar energy plan recast of existing debt so it can raise capital and continuing their operation and it focuses on improving its balance sheet after a turbulent period that included heavy capital expenditure and regulatory setbacks. Debt financing is temporary recovery method to regain a stability of liquidity. But in case continue lead to bankruptcy.

\section{ii. $\quad$ Case Study on Suzlon Energy Company}

The article published from Business Line on $28^{\text {th }}$ November 2012 regarding debt of Rs 250 crore in two equal instalments if they are to restructure the company's Rs 10,829-crore debt ${ }^{[11]}$. Twenty-one banks and financial institutions lend loan exposure to the wind energy major as follows include

\begin{tabular}{|l|l|}
\hline Bank & Loan amount \\
\hline SBI & Rs 1,804 crore \\
\hline IDBI Bank & Rs 1,692 crore \\
\hline Punjab National Bank & Rs 857 crore \\
\hline Indian Overseas Bank & Rs 855 crore \\
\hline Bank of Baroda & Rs 845 crore \\
\hline Life Insurance Corporation of India & Rs 622 crore \\
\hline
\end{tabular}

\section{- Suggestion}

The company sell its non-core assets and realise receivables to debtors for refinancing of debt. The delay in sale makes cash flow ring-fenced, shortfall in money margin and reduce liquidity position due to higher cost of borrowing, lead to declined profit margin, cut in manpower, operating cost etc, it affect the growth of economy. Debt Refinancing protect companies from shutdown and pick up to run in long run for that companies concentrate more in payment of interest rate and borrowing level on asset.

\section{CONCLUSION}

Debt Refinancing needs an approval from business \& industry for guaranteed loan program before applying debt refinances. In order to improve cash flow and support to expansion of business in corporate mainly emerged. Today corporate undergo refinance to perform operation and survival of business in overseas market. The decline the value of currency may cut down the interest rate as lower.

In this case Essar group and Suzlon energy companies raise their capital fund through debt refinancing by reducing the interest rate. When interest rates drop, the company needs to refinance its debt at the new rate. In this case, the company may refinance by issuing new bonds at the lower coupon rate and use the proceeds to buy back the older bonds. These efforts are neither driven by any compulsion to refinance or restructuring but the strategy of pruning financing costs as much as possible.

\section{REFERENCE}

\section{Source: Internet}

[1] http://www.investopedia.com/terms/c/corporaterefinancing.asp\#axzz2Cvd6cAfU.

[2] http://www.investorwords.com/4115/refinancing.html

[3] http://www.referenceforbusiness.com/encyclopedia/ProRes/Refinancing.html\#ixzz2DPr5aho3

[4] http://www.google.com/refinance.pdf

[5] www.google.comldebtl Debt Consolidation Loans_Mortgage Refinance_Compare Loans.htm

[6] http://google.com/roland_berger_european_refinancing_2012_20120323.p df

[7] http://www.bloomberg.com/news/2012-11-20/billionaire-brothers-debtrecast-boosts-essar-bond-india-credit.html

[8] http://www.bloomberg.com/news/2012-11-07/essar-said-to-plan-4-8billion-debt-refinance corporation

[9] http://articles.economictimes.indiatimes.com/2012-0921/news/34002191_1_essar-ports-crore-debt-interest-payment

[10] http://www.business-standard.com/india/news/essar-energy-looks-to-cutrupee-debt-improve-financials/193363/on

[11] http://www.thehindubusinessline.com/companies/lenders-ask-suzlon-tobring-in-rs-250-cr-for-debt-recast/article4140774.ece 


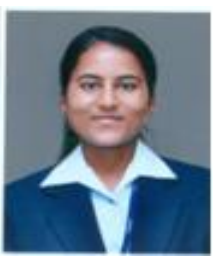

I am A.Hema, MBA, (MPhil), this seed start from beautiful town Udumalpet, born on 19.08.1990. She is currently pursuing Master of Philosophy in Management at Sree Saraswathi Thyagaraja College, pollachi, India with Master of Business Administration with specialised in Finance, from Coimbatore Institute of Management And Technology in First class distinction. She did Bachelor degree in BBM (CA) from Sir GVG Visalakshi College for women, Udumalpet. Under, Mr.G. Manokaran MBA, MPhil, M $\mathrm{Com}, \mathrm{PhD}$ helped and guided in her research work in all ways. Presented a paper in National and International Conference within India and Published in article Bonfring National journal with ISBN No: 978-93-82338-38-3. 